\title{
FGF2 Gene
}

National Cancer Institute

\section{Source}

National Cancer Institute. FGF2 Gene. NCI Thesaurus. Code C18569.

This gene is involved in angiogenesis, development and cell cycle control. 